\title{
Apelin-13 induces MCF-7 cell proliferation and invasion via phosphorylation of $\mathrm{ERK}_{1 / 2}$
}

\author{
XUEWEI PENG, FENGYU LI, PING WANG, SHENGNAN JIA, LILI SUN and HONGLIANG HUO \\ School of Life Sciences, Northeast Normal University, Changchun, Jilin 130024, P.R. China
}

Received January 1, 2015; Accepted June 22, 2015

DOI: 10.3892/ijmm.2015.2265

\begin{abstract}
Apelin-13 is extensively expressed in various tissues, particularly breast tissue. Apelin-13 has been shown to promote tumor proliferation in various types of cancer, including hepatocellular, lung and ovarian cancer. However, the effect and molecular mechanism of apelin-13 in breast cancer cells remains unclear. The present study investigated the effect of apelin-13 on MCF-7. Therefore, cell proliferation was determined by MTT and flow cytometry analysis. The results revealed that apelin-13 markedly increased cell proliferation. Transwell assays demonstrated that apelin-13 increased MCF-7 cell invasion. Apelin-13 also markedly increased the expression of cyclin D1, extracellular matrix metalloproteinase-1 and amplified in breast cancer 1 (AIB1) in a dose-dependent manner by polymerase chain reaction assays. To study the molecular mechanism, cell proliferation, invasion and cyclin D1 were inhibited by pre-treatment with $10 \mu \mathrm{M}$ of PD98059 (ERK (ER/2 $_{1}$ inhibitor). Western blotting results suggested that apelin-13 significantly enhances the expression of $\mathrm{p}-\mathrm{ERK}_{1 / 2}$ in a concentration-dependent manner. In conclusion, the results suggest that apelin-13 promoted MCF-7 cell proliferation and invasion via the $\mathrm{ERK}_{1 / 2} / \mathrm{AIB1}$ signaling pathway.
\end{abstract}

\section{Introduction}

Apelin was first identified as an endogenous ligand for the orphan $\mathrm{G}$ protein-coupled receptor APJ from bovine stomach extracts in 1998 (1). Apelin/APJ are widely expressed in various tissues, including the heart, lung, liver, brain and bone (2). They have multiple biological activities, including regulation of food intake, blood pressure and endoplasmic reticulum (ER) stress (3-6). Several studies have shown that

Correspondence to: Professor Hongliang Huo, School of Life Sciences, Northeast Normal University, 5268 Renmin Street, Changchun, Jilin 130024, P.R. China

E-mail: pengxw933@nenu.edu.cn

Key words: apelin-13, proliferation, invasion, amplified in breast cancer 1, extracellular signal-regulated kinase apelin was abundantly expressed in malignant carcinoma tissues, where it promoted the occurrence, proliferation and metastasis of cancer cells. Li et al found that apelin-13 increased vascular smooth muscle cell proliferation by upregulating the expression of cyclin D1, which was involved in an ERK-dependent activation of the Jagged-1/Notch3 signaling pathway (7). Apelin is associated with tumor cell proliferation, invasion and tube formation in vitro (8-10). Apelin-13 could induce lung adenocarcinoma cell proliferation and autophagy via ERK $_{1 / 2}$ pathway (9). Apelin may be associated with angiogenesis and tumorigenesis. Recent studies demonstrated that a high level of apelin mRNA is expressed in a human breast carcinoma cell line (11). However, the mechanism of apelin-13 in breast cancer remains unknown.

The cell cycle is one of the most important activities in cell life processes; the $G_{1}$ phase activation is the critical process. Cyclin D1 is responsible for cell cycle progression in the transition from $\mathrm{G}_{0} / \mathrm{G}_{1}$ to $\mathrm{S}$ phase. The overexpression of cyclin D1 was identified in lung and breast cancer. Cyclin D1 may have an important role in the generation and development of human breast cancer. Extracellular matrix metalloproteinases (MMPs) are a family of $\mathrm{Zn}^{2+}$-dependent enzymes. MMP-1 (collagenase I) specifically degrades collagen I, a major component of the extracellular matrix (ECM). In a previous study, overexpression of MMP-1 was associated with advanced stages of breast cancer and may be a predictive marker for invasive disease (12). In the present study, the correlation of apelin-13, cyclin D1 and MMP-1 in MCF-7 cells was evaluated.

The oncogene nuclear receptor coactivator amplified in breast cancer 1 (AIB1) is a transcriptional coactivator that is overexpressed in breast cancer. AIB1 has been identified as amplified in 2-10\% of human breast cancer tumors and overexpressed in 30-60\% (13-17). The correlation between AIB1 and proliferation has also been shown for prostate (18), esophageal squamous cell (19) and urothelial cancer (20). AIB1 can interact with other signaling pathways (21-23). Therefore, the association between AIB1 and apelin-13 was investigated, as well as their effect on proliferation and invasion with or without PD98059 treatment.

The present study reported that apelin-13 stimulated the proliferation of MCF-7 and promoted the expression of AIB1 and cyclin D1. The ERK $\mathrm{E}_{1 / 2}$ inhibitor PD98059 attenuated the expression of cyclin D1, AIB1 and MMP-1 and prevented apelin-13-induced MCF-7 proliferation and invasion. The 
study provided evidence that the effects of apelin-13 on MCF-7 proliferation and invasion were partly mediated by the ERK/AIB1/cyclin D1/MMP-1 signaling pathways.

\section{Materials and methods}

Cell culture. MCF-7 human breast adenocarcinoma cells (ATCC, Manassas, VA, USA) were maintained in Dulbecco's modified Eagle's medium (DMEM) supplemented with $10 \%$ (v/v) fetal bovine serum (FBS), 100 units penicillin and $100 \mu \mathrm{g}$ streptomycin (all from Gibco-BRL, Gaithersburg, MD, USA). The cells were maintained in the growing medium in a humidified $5 \% \mathrm{CO}_{2}$ atmosphere at $37^{\circ} \mathrm{C}$.

MTT assay. MCF-7 cells were cultured in 96-well plates $\left(5 \times 10^{4}\right.$ cells $)$ and were synchronized for $24 \mathrm{~h}$ in DMEM containing $0.1 \%$ FBS. After treatment with $(0.01,0.1$ and $10 \mu \mathrm{M}$ ) apelin-13 or pre-treatment with PD98059 (Sigma, St. Louis, MO, USA) for $1 \mathrm{~h}$ followed by the addition of $10 \mu \mathrm{M}$ apelin-13 for $24 \mathrm{~h}$, the cells were incubated with MTT solution (Invitrogen Life Technologies, Carlsbad, CA, USA) for $4 \mathrm{~h}$ at $37^{\circ} \mathrm{C}$. Non-reduced MTT was removed by aspiration and the formazan crystals were dissolved in dimethyl sulfoxide $\left(150 \mu \mathrm{l} /\right.$ well) for $30 \mathrm{~min}$ at $37^{\circ} \mathrm{C}$. The formazan was spectroscopically quantified at $490 \mathrm{~nm}$ using a Bio-Rad Microplate Reader (Bio-Rad, Hercules, CA, USA).

Cell proliferation assay. MCF-7 cells in $3 \mathrm{ml}$ of DMEM with $10 \%$ FBS were plated in a 6-well plate at a density of $1 \times 10^{6}$ cells $/$ well and incubated at $37^{\circ} \mathrm{C}$ with $5 \% \mathrm{CO}_{2}$. After $24 \mathrm{~h}$, the cells were treated with apelin-13 $(0.01,0.1$ and $10 \mu \mathrm{M})$ in serum-free medium and incubated for $12 \mathrm{~h}$ under similar conditions. BrdU (Amresco LLC, Solon, OH, USA) was added to the culture medium $1 \mathrm{~h}$ before the end of the 24-h incubation period, cells were collected and each cell sample was subsequently analyzed by flow cytometry.

Tumor invasion assay. The invasion of MCF-7 cells was measured using Transwell chambers (BD Biosciences, Franklin Lakes, NJ, USA). After $12 \mathrm{~h}$ of serum depletion, MCF-7 cells were detached and resuspended with DMEM containing $0.1 \%$ bovine serum albumin (BSA) and added to the upper compartment with $2 \times 10^{5}$ cells per each Transwell insert. The lower compartment of each well contained $0.5 \mathrm{ml}$ of DMEM with $0.1 \%$ BSA with apelin- $13(0.01,0.1$ and $10 \mu \mathrm{M})$ or pre-treatment with PD98059 for $1 \mathrm{~h}$ followed by the addition of $10 \mu \mathrm{M}$ apelin-13. After $6 \mathrm{~h}$ of incubation, the upper compartment was fixed and stained with $0.1 \%$ crystal violet (Zhuo Kang Biological Technology Co., Ltd., Shanghai, China) for $10 \mathrm{~min}$. The number of invasion cells in 10 fields per filter was counted using a microscope (magnification, $\mathrm{x} 100$ ). Crystal violet was eluted with $33 \%$ acetic acid, and the eluent optical density value was measured at $570 \mathrm{~nm}$ using the Bio-Rad Microplate Reader.

RNA extraction. Total RNA from MCF-7 cells was extracted with TRIzol reagent (Invitrogen Japan K.K., Tokyo, Japan) following the manufacturer's instructions, and subsequently frozen at $-20^{\circ} \mathrm{C}$ in RNase-free water [Takara Biotechnology (Dalian) Co., Ltd., Liaoning, China]. Single-stranded cDNA was reverse transcribed from total RNA (500 ng) using a First
Strand cDNA Synthesis kit for RT-PCR [Takara Biotechnology (Dalian) Co., Ltd.] and a random primer. Reverse transcription conditions were 1 cycle of $30^{\circ} \mathrm{C}$ for $10 \mathrm{~min}, 45^{\circ} \mathrm{C}$ for $30 \mathrm{~min}$, $95^{\circ} \mathrm{C}$ for $5 \mathrm{~min}$, and finally $5^{\circ} \mathrm{C}$ for $5 \mathrm{~min}$.

Reverse transcription polymerase chain reaction (RT-PCR). cDNA $(1 \mu \mathrm{g})$ was reverse-transcribed according to the manufacturer's instructions [Takara Biotechnology (Dalian) Co., Ltd.]. The sequences for the sense and antisense primers respectively were: Cyclin D1, 5'-GATGCCAACCTCCTC AACGAC-3' and 5'-CTCCTCGCACTTCTGTTCCTC-3' (171 bp); MMP-1, 5'-CCTTCTACCCGGAAGTTGAG-3' and 5'-TCCGTGTAGCACATTCTGTC-3' (158 bp); AIB1, 5'-CCA GCTGCACACTCTTCTCA-3' and 5'-TAAGAAAACCCT GCTGGGGC-3' (488 bp); and GAPDH, 5'-TCGGAGTCA ACGGATTTGGTCGTA-3' and 5'-TGGCATGGACTGTGG TCATGAGTC-3' (525 bp). The cyclin D1 and MMP-1 amplification program consisted of $5 \mathrm{~min}$ for initial denaturation at $95^{\circ} \mathrm{C}$ followed by 35 cycles at $94^{\circ} \mathrm{C}$ for $30 \mathrm{sec}, 60^{\circ} \mathrm{C}$ for $30 \mathrm{sec}$, $72^{\circ} \mathrm{C}$ for $30 \mathrm{sec}$ and $7 \mathrm{~min}$ for the final extension at $72^{\circ} \mathrm{C}$. The AIB1 and GAPDH amplification program consisted of $5 \mathrm{~min}$ for initial denaturation at $95^{\circ} \mathrm{C}$ followed by 35 cycles at $94^{\circ} \mathrm{C}$ for $30 \mathrm{sec}, 60^{\circ} \mathrm{C}$ for $30 \mathrm{sec}, 72^{\circ} \mathrm{C}$ for $40 \mathrm{sec}$ and $7 \mathrm{~min}$ for the final extension at $72^{\circ} \mathrm{C}$. The PCR products underwent electrophoresis in a $1.5 \%(\mathrm{w} / \mathrm{v})$ agarose gel (Biowest, Barcelona, Spain), with a thickness $\sim 0.5 \mathrm{~cm}$. The gel imaging was scanned and the optical density of the electrophoretic bands was determined using BandScan 5.0 software (Glyko, Novato, CA, USA).

Enzyme-linked immunosorbent assay (ELISA). MCF-7 cells were plated at a density of $2 \times 10^{5}$ cells/well in 96 -well plates. The concentrations of MMP-1 and cyclin D1 were quantified by ELISA kits (Invitrogen Life Technologies). The colorimetric reaction was measured using a Microplate Reader (Bio-Rad) at $450 \mathrm{~nm}$ wavelength.

Western blotting. To assay the levels of protein expression and phosphorylation of $\mathrm{p} 44 / 42 \mathrm{ERK}_{1 / 2}$ and $\beta$-actin, MCF-7 cells were cultured in 6-well plates and treated with 0.01 , 0.1 and $10 \mu \mathrm{M}$ of recombinant apelin-13 or pre-treatment with PD98059 for $1 \mathrm{~h}$ followed by the addition of $10 \mu \mathrm{M}$ apelin-13 for $12 \mathrm{~h}$. For immunoblotting, cells were washed twice with ice-cold phosphate-buffered saline and subsequently lysed in radioimmunoprecipitation assay buffer with a cocktail of protease inhibitors on ice for $15 \mathrm{~min}$. Following centrifugation at $13,000 \mathrm{x} \mathrm{g}$ for $20 \mathrm{~min}$ at $4^{\circ} \mathrm{C}$, the quantity of protein in the supernatants was detected using the bicinchoninic acid Protein Assay kit (Beijing Solarbio Science \& Technology Co., Ltd., Shanghai, China). The protein samples were separated by SDS-PAGE and were transferred onto PVDF membranes (Millipore, Billerica, MA, USA). Following blocking with $5 \%$ non-fat milk for $1 \mathrm{~h}$, the membranes were incubated with primary antibodies specific for phospho-p44/42 $\mathrm{ERK}_{1 / 2}$ $(1: 2,000 ; \# 4370)$ and $\beta$-actin $(1: 2,000 ; \# 4970)$ (all from Cell Signaling Technology, Inc., Danvers, MA, USA) overnight at $4^{\circ} \mathrm{C}$. Blots underwent three 8 min washes with Tris-buffered saline with $0.1 \%$ Tween-20 and were incubated with secondary antibodies IgG (1:8,000; \#14708; Cell Signaling Technology, Inc.) for $1 \mathrm{~h}$. The membranes were washed as above and the 
A

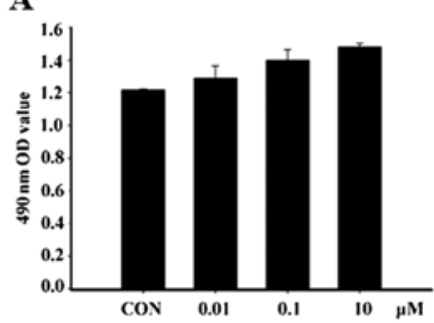

B

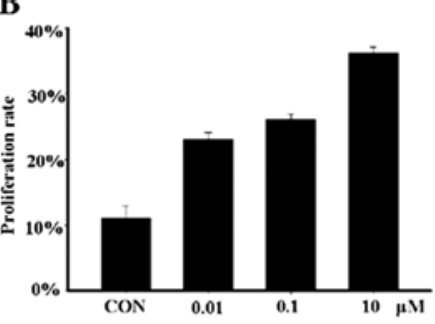

C

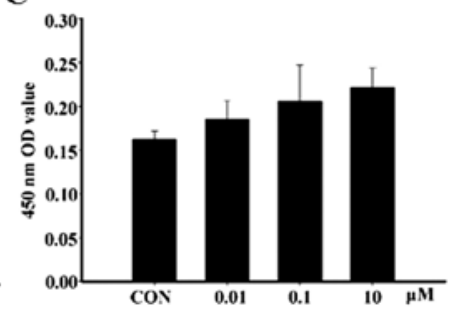

D

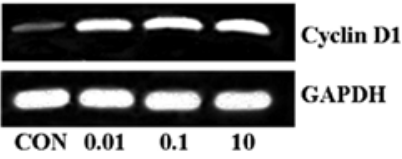

Figure 1. Effects of apelin-13 on MCF-7 cell proliferation and cyclin D1. (A) The MCF-7 cell proliferation was measured by the MTT assay. The optical density (OD) value was measured at $490 \mathrm{~nm}$ following treatment with apelin-13 for $24 \mathrm{~h}$. (B) The effects of apelin-13 on MCF-7 proliferation rate. (C) Determination of expression by human cyclin D1 ELISA kit following treatment with exogenous apelin-13 for $12 \mathrm{~h}$. Values are presented as mean \pm standard error of the mean of triplicates. (D) Apelin-13 promotes cyclin D1 mRNA expression. The mRNA levels of cyclin D1 and GAPDH were determined using reverse transcription-polymerase chain reaction following treatment with exogenous apelin- 13 for $12 \mathrm{~h}$. Data are expressed as the mean \pm standard deviation of six independent experiments.

A

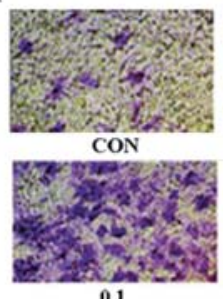

0.1

C

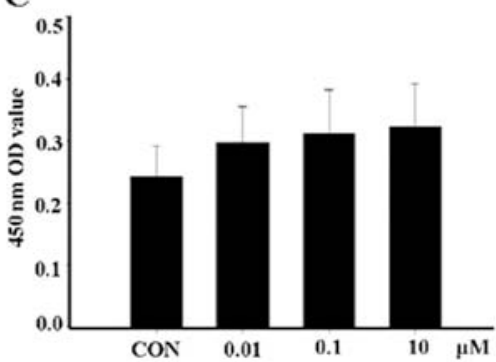

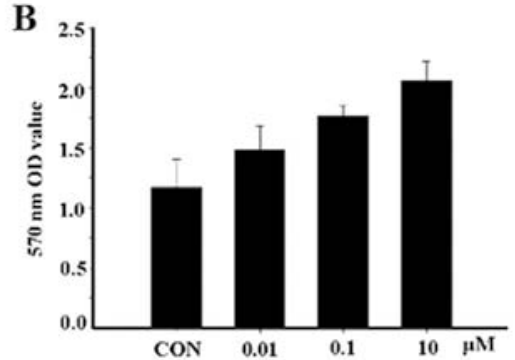

D

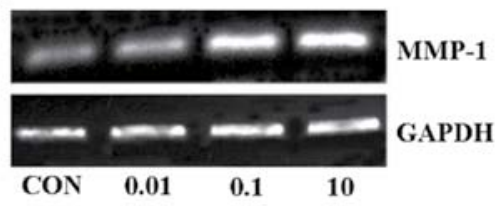

Figure 2. Apelin-13 promotes invasion of MCF-7 and expression of extracellular matrix metalloproteinase (MMP)-1. (A) MCF-7 cells were plated in the upper chamber. Apelin $(0.01,0.1$ and $10 \mu \mathrm{M})$ was added to the lower chamber, and the cells were allowed to invade for $6 \mathrm{~h}$. The cells were fixed and stained with crystal violet. The invasion cells were counted by an investigator blinded to the sample (magnification, x100). (B) Crystal violet 570 nm optical density (OD) value was measured by elution with $33 \%$ acetic acid. (C) Determination of cell culture supernatant expression by human MMP-1 ELISA kit following treatment with exogenous apelin-13 for $12 \mathrm{~h}$. Values are presented as mean \pm standard error of the mean of triplicates. (D) Apelin-13 promotes MMP-1 mRNA expression. The mRNA levels of MMP-1 and GAPDH were determined using reverse transcription-polymerase chain reaction following treatment with exogenous apelin-13 for $12 \mathrm{~h}$. Data are expressed as the mean \pm standard deviation of six independent experiments.

bands were scanned by the Tanon 5500 fully automatic digital gel image analysis system (Tanon Science \& Technology Co., Ltd., Shanghai, China).

Statistical analysis. The results are expressed as the mean \pm standard deviation (SD). The mean and SD of each dataset were calculated using the SigmaPlot 10.0 software (Systat Software, San Jose, CA, USA). The differences between groups were assessed using the t-test to determine P-values $(\mathrm{P}<0.05$ was considered to indicate a clear difference, and $\mathrm{P}<0.01$ was considered to indicate a statistically significant difference).

\section{Results}

Apelin-13 promotes the proliferation of MCF-7 cells and cyclin D1 expression. Previous studies have suggested that apelin stimulates cell proliferation and invasion in several cell lines, including endothelial, lung and oral squamous cells $(7,9,10)$. The present study examined the effects of apelin-13 on MCF-7 proliferation and invasion. Using the MTT and flow cytometry assay, the treatment of MCF-7 with apelin-13 was demonstrated to significantly increase cell proliferation (Fig. 1A and B). In order to explore the effect of apelin-13 on cyclins, the expression level of cyclin D1 was detected by ELISA and RT-PCR analysis. The results showed that the protein and mRNA expression levels of cyclin D1 were significantly increased after MCF-7 cells were incubated with apelin-13 for $12 \mathrm{~h}$, suggesting that apelin-13 affects the cell cycle through increasing cyclin D1 expression, and subsequently induces MCF-7 cell proliferation (Fig. 1C and D).

Apelin-13 promotes the invasion of MCF-7 cells and MMP-1 expression. Degradation of the stromal connective tissue and basement membrane components are critical elements in tumor invasion. This is particularly true regarding the 


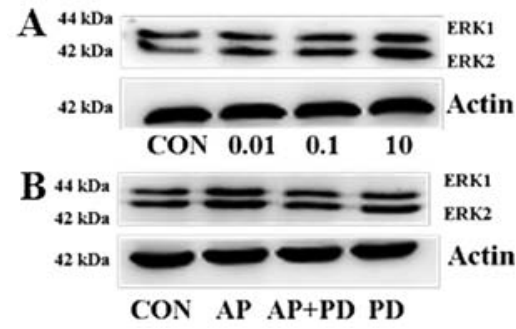

Figure 3. Effect of apelin-13 on $\mathrm{ERK}_{1 / 2}$ phosphorylation in MCF-7 cells. (A) After MCF-7 cells were treated with apelin-13 (0.01, 0.1 and $10 \mu \mathrm{M})$ for $12 \mathrm{~h}$, cell lysates were subjected to western blotting and incubated with antibodies against $\mathrm{ERK}_{1 / 2}$ (upper panel). (B) MCF-7 cells were treated with $10 \mu \mathrm{M}$ apelin-13 for $12 \mathrm{~h}$, pre-treated with $10 \mu \mathrm{M}$ of PD98059 for $1 \mathrm{~h}$, and subsequently the phosphorylation of $\mathrm{ERK}_{1 / 2}$ (upper panel) was analyzed. $\beta$-actin was used as the loading control (lower panel). Data are expressed as the mean \pm standard deviation of three independent experiments.
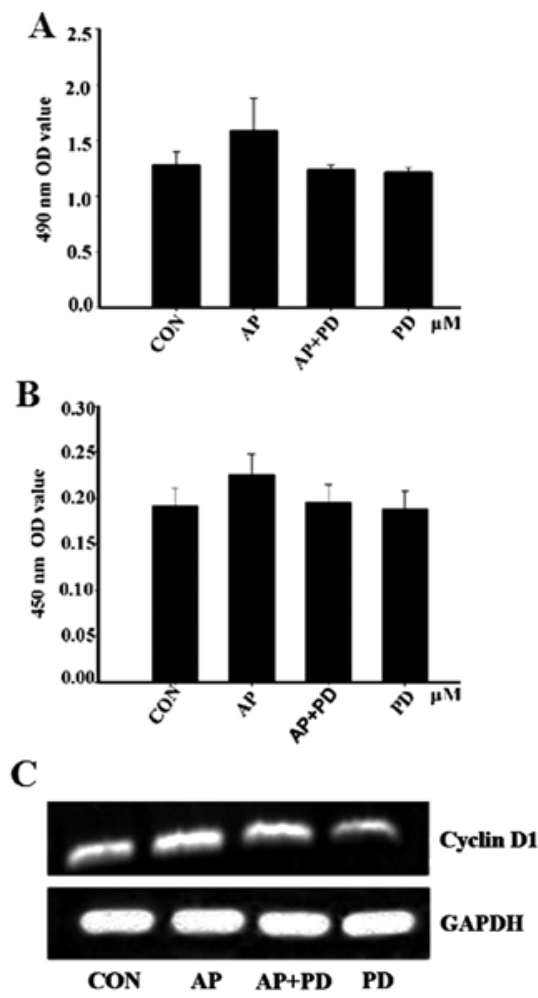

Figure 4. Effects of the specific $\mathrm{ERK}_{1 / 2}$ inhibitor PD98059 on the proliferation and expression of cyclin D1 of MCF-7 cells induced by apelin-13. (A-C) MCF-7 cells were pre-treated with $10 \mu \mathrm{M}$ PD98059 for $1 \mathrm{~h}$ followed by treatment with $10 \mu \mathrm{M}$ apelin-13. (A) MCF-7 proliferation was measured with the MTT assay for $24 \mathrm{~h}$. (B) The protein levels of cyclin D1 were measured using the ELISA kit for $12 \mathrm{~h}$. (C) The mRNA levels of cyclin D1 and GAPDH were determined using reverse transcription-polymerase chain reaction following treatment with exogenous apelin-13 for $12 \mathrm{~h}$. Data are expressed as the mean \pm standard deviation of six independent experiments.

interstitial collagens, which were degraded by MMPs. MMP-1 is a member of a family of enzymes that can degrade the majority of ECM macromolecules, particularly types I and III. Therefore, whether apelin-13 could promote MCF-7 cell invasion and MMP-1 expression was investigated. As hypothesized, the results revealed that the quantity of apelin-13-treated cells passing through the basement membrane into the lower compartment was significantly greater compared with that of the control group (Fig. 2A and B). This finding suggests that apelin-13 can promote the invasion of MCF-7 cells. Subsequently, the expression of MMP-1 was examined and the expression of the proteins was closely correlated with apelin-13 (Fig. 2C and D). The results showed that MMP-1 may be critically involved in the metastasis of tumors.

Apelin-13 activates the phosphorylation of $E R K_{1 / 2}$ in MCF-7 cells. To evaluate the potential signaling pathways involved in apelin-13-induced MCF-7 cell proliferation and invasion, the role of apelin-13 on $\mathrm{ERK}_{1 / 2}$ was examined by western blotting. As is shown in Fig. 3A, dose-dependent effects of apelin-13 on $\mathrm{ERK}_{1 / 2}$ activation were determined. $\mathrm{ERK}_{1 / 2}$ reached maximal phosphorylation upon treatment with apelin-13 at $10 \mu \mathrm{M}$. PD98059 (an inhibitor of $\mathrm{ERK}_{1 / 2}$ ) significantly inhibited the overexpression of apelin-13-induced $\mathrm{ERK}_{1 / 2}$ phosphorylation (Fig. 3B).

PD98059 inhibits apelin-13-induced MCF-7 cell proliferation. To further evaluate whether $\mathrm{ERK}_{1 / 2}$ has any effect on apelin-13-induced MCF-7 cell proliferation, the protein and mRNA expression levels of cyclin D1 were detected. MTT analysis indicated that pre-treatment with PD98059 prevented apelin-13-induced MCF-7 proliferation (Fig. 4A). The data were confirmed by ELISA and RT-PCR. The levels of cyclin D1 expression were decreased following pre-incubation with PD98059 for $1 \mathrm{~h}$ (Fig. 4B and C). These results suggested that apelin-13 influenced MCF-7 cell proliferation, possibly via $\mathrm{ERK}_{1 / 2}$ signaling cascades.

PD98059 inhibits apelin-13-induced MCF-7 cell invasion. To address the functional significance of apelin-mediated MCF-7 cell invasion in the context of $\mathrm{ERK}_{1 / 2}$ activation, the effect of PD98059 upon MCF-7 cell invasion and MMP-1 was examined. MCF-7 cell invasion and the expression of MMP-1 were reduced by PD98059 (Fig. 5). These results suggested that apelin-13-induced invasion of MCF-7 cells and ERK $_{1 / 2}$ may be involved in the signaling pathway.

Apelin-13 promotes AIBI mRNA expression via ERK $K_{1 / 2}$. AIB1 amplification and overexpression are associated with proliferation, invasion and poor prognosis in breast cancer. Therefore, AIB1 mRNA expression was detected by RT-PCR. Apelin-13 could promote the endogenous levels of AIB1 mRNA in a concentration-dependent manner. Additionally, the molecular mechanism of AIB1 overexpression was observed following treatment with the apelin-13. The result showed that PD98059 inhibited AIB1 expression. Together, these data suggested that apelin-13 promoted AIB1 expression via the $\mathrm{ERK}_{1 / 2}$ signal pathway (Fig. 6).

\section{Discussion}

In the present study, the regulation and signaling of apelin on breast cancer cells were investigated. A previous finding identified the role for AIB1 in breast cancer and described a new mechanism of ER $\alpha / A I B 1$ gene regulation, which could regulate cyclin D1 genes depending on the promoter context (24). The coactivator protein AIB1 has previously been associated with the initiation of breast cancer. The MMPs are indicated in the 
A

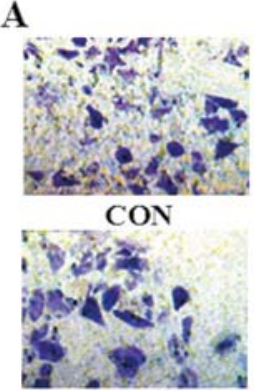

$\mathrm{C}_{0}$
$\mathrm{AP}+\mathrm{PD}$

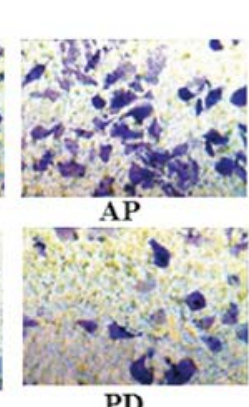

PD

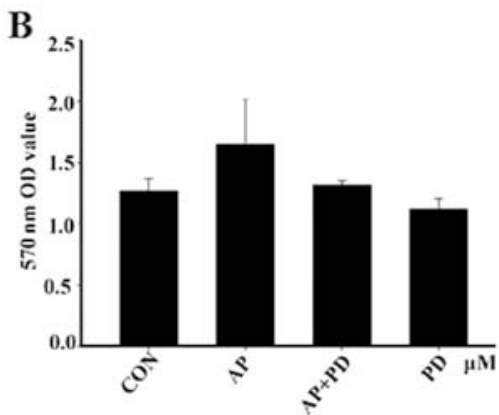

D
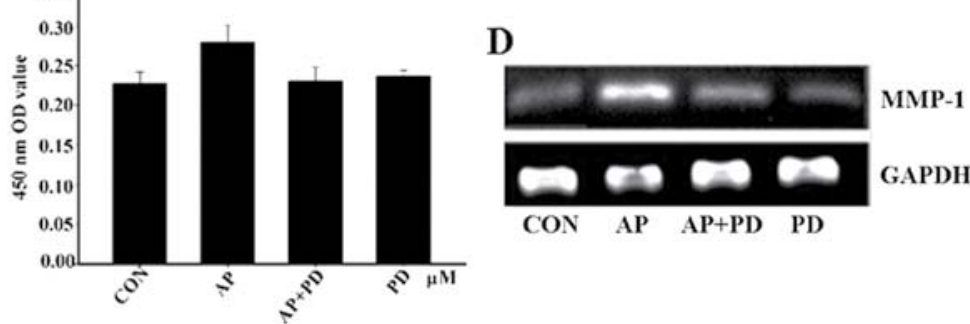

Figure 5. Effects of the specific ERK $\mathrm{L}_{1 / 2}$ inhibitor PD98059 on the invasion and expression of extracellular matrix metalloproteinase (MMP)-1 of MCF-7 cells induced by apelin-13. (A-D) MCF-7 cells were pre-treated with $10 \mu \mathrm{M}$ PD98059 for $1 \mathrm{~h}$ followed by treatment with $10 \mu \mathrm{M}$ apelin-13. (A) MCF-7 cell invasion was measured with the Transwell assay. (B) Crystal violet $570 \mathrm{~nm}$ optical density value was measured by elution with $33 \%$ acetic acid. (C) The protein levels of MMP-1 were measured using the ELISA kit. (D) The mRNA levels of MMP-1 and GAPDH were determined using reverse transcription-polymerase chain reaction. Data are expressed as the mean \pm standard deviation of six independent experiments.

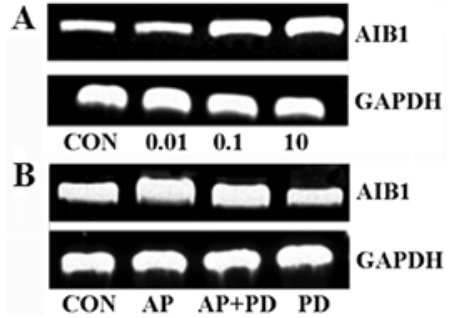

Figure 6. Apelin-13-induced amplified in breast cancer 1 (AIB1) expression via $\mathrm{ERK}_{1 / 2}$ signaling pathway. The total RNA was isolated from the cells, and the mRNA levels of AIB1 and GAPDH were determined using reverse transcription-polymerase chain reaction. (A) MCF-7 cells were treated with apelin-13 $(0.01,0.1$ and $10 \mu \mathrm{M})$ for $12 \mathrm{~h}$. (B) MCF-7 cells were treated with $10 \mu \mathrm{M}$ apelin-13 for $12 \mathrm{~h}$ following pre-treatment with $10 \mu \mathrm{M}$ of PD98059 for $1 \mathrm{~h}$. Data are expressed as the mean \pm standard deviation of six independent experiments.

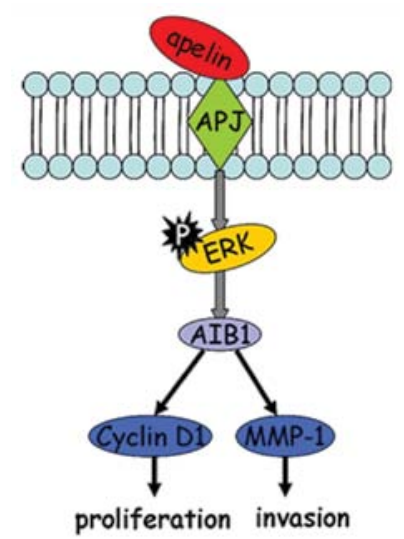

Figure 7. Schematic depiction of apelin-13 induction via the $\mathrm{ERK}_{1 / 2} / \mathrm{AIB} 1$ pathway. Apelin/APJ phosphorylates $\mathrm{ERK}_{1 / 2}$ leading to activation of amplified in breast cancer 1 (AIB1) transcription. AIB1-mediated expression of cyclin D1 and extracellular matrix metalloproteinase (MMP)-1 positively promote MCF-7 proliferation and invasion. basic processes of tumor progression, such as degradation of basement membrane and ECM, stimulation of cellular proliferation and invasion. In the present study, several methods by which apelin-13 regulated cell proliferation, invasion and the underlying mechanisms and signaling pathways were demonstrated as follows: i) MCF-7 cell proliferation was documented by the MTT and flow cytometry assays; ii) MCF-7 cell invasion was measured by the Transwell assay; iii) cyclin D1, MMP-1 and AIB1 were transcriptionally upregulated by apelin-13, induced in a dose-dependent manner; iv) apelin-13 enhanced the phosphorylation of $\mathrm{ERK}_{1 / 2}$ in a dose-dependent manner; and v) cyclin D1, MMP-1 and AIB1 were transcriptionally inhibited by PD98059. These results showed that apelin-13 treatment promoted human MCF-7 proliferation and invasion in a dose-dependent manner, which was consistent with our previously reported results (Fig. 1A and B; Fig. 2A and B). To further explore the role of apelin-13-induced proliferation and invasion of MCF-7 cells, the expression of cyclin D1 and MMP-1 were detected using ELISA and RT-PCR assays. The results revealed that the expression levels were upregulated in a concentration-dependent manner (Fig. 1C and D; Fig. 2C and D). Finally, the downstream pathways that contribute to proliferating MCF-7 cells were investigated. The apelin/APJ system has been shown to induce various signaling pathways, including the JNK, P38 MAPK and ERK I/2 $_{2}$ pathways. The present results showed that apelin-13 promoted the expression of $\mathrm{ERK}_{1 / 2}$ phosphorylation and PD98059 (an ERK $_{1 / 2}$ inhibitor) inhibited MCF-7 cell proliferation and invasion induced by apelin-13 (Figs. 3-5). These data also revealed that the activation of the $\mathrm{ERK}_{1 / 2}$ pathway could regulate cyclin D1, MMP-1 and ERK ${ }_{1 / 2}$ expression. PD98059 was able to repress cyclin D1 and MMP-1 expression (Fig. 4B and C; Fig. 5C and D). These results indicated that apelin-13 induced MCF-7 cell proliferation and invasion via the ERK signaling 
pathway. Additionally, AIB1 has an important role that is relevant to breast cancer cell survival and proliferation. Activation of the $\mathrm{ERK}_{1 / 2}$ pathway upon growth factor or hormone stimulation led to the subsequent transactivation of AIB1 in MCF-7 breast cancer cells (25). ERK $\mathrm{E}_{1 / 2}$ signaling was affected in mice with reduced AIB1 levels during Neu-induced tumorigenesis (26). Therefore, the effects of apelin-13 and PD98059 on AIB1 mRNA expression were analyzed. The results suggested that AIB1 expression was promoted by apelin-13 and reduced following pre-treatment with PD98059 (Fig. 6). These data suggested that AIB1 may have an important role in tumor maintenance by regulating cyclin D1 and MMP-1 in breast cancer cells, which may be due to the activation of the ERK cascade and thereby resulting in activation of the cyclin D1 promoter.

In conclusion, as shown in Fig. 7, apelin-13-induced MCF-7 proliferation and invasion was mediated through the $\mathrm{ERK}_{1 / 2} / \mathrm{AIB1}$ signaling pathway, further leading to transcriptional activation of downstream target proteins cyclin D1 and MMP-1. This novel finding not only revealed the mechanism of apelin-13-induced MCF-7 cell proliferation, but also provided certain potential targets for future treatment of breast cancer.

\section{Acknowledgements}

The present study was supported by the Natural Science Fund of Jilin (grant no. 201215001) and the Jilin Province Science and Technology Research Projects (grant no. 20140204059YY).

\section{References}

1. Tatemoto K, Hosoya M, Habata Y, et al: Isolation and characterization of a novel endogenous peptide ligand for the human APJ receptor. Biochem Biophys Res Commun 251: 471-476, 1998.

2. O'Carroll AM, Selby TL, Palkovits M and Lolait SJ: Distribution of mRNA encoding B78/apj, the rat homologue of the human APJ receptor, and its endogenous ligand apelin in brain and peripheral tissues. Biochim Biophys Acta 1492: 72-80, 2000.

3. Sunter D, Hewson AK and Dickson SL: Intracerebroventricular injection of apelin-13 reduces food intake in the rat. Neurosci Lett 353: 1-4, 2003.

4. Ishida J, Hashimoto T, Hashimoto Y, et al: Regulatory roles for APJ, a seven-transmembrane receptor related to angiotensin-type 1 receptor in blood pressure in vivo. J Biol Chem 279: 26274-26279, 2004.

5. Akcılar R, Turgut S, Caner V, Akcılar A, Ayada C, Elmas L and Özcan TO: Apelin effects on blood pressure and RAS in DOCA-salt-induced hypertensive rats. Clin Exp Hypertens 35: 550-557, 2013

6. Jeong K, Oh Y, Kim S-J, Kim H, Park KC, Kim SS, Ha J, Kang I and Choe W: Apelin is transcriptionally regulated by ER stress-induced ATF4 expression via a p38 MAPK-dependent pathway. Apoptosis 19: 1399-1410, 2014.

7. Li L, Li L, Xie F, Zhang Z, Guo Y, Tang G, Lv D, Lu Q, Chen L and Li J: Jagged-1/Notch3 signaling transduction pathway is involved in apelin-13-induced vascular smooth muscle cells proliferation. Acta Biochim Biophys Sin (Shanghai) 45: 875-881, 2013.

8. Masri B, Morin N, Cornu M, Knibiehler B and Audigier Y: Apelin (65-77) activates p70 S6 kinase and is mitogenic for umbilical endothelial cells. FASEB J 18: 1909-1911, 2004.
9. Yang L, Su T, Lv D, Xie F, Liu W, Cao J, Sheikh IA, Qin X, Li L and Chen L: ERK1/2 mediates lung adenocarcinoma cell proliferation and autophagy induced by apelin-13. Acta Biochim Biophys Sin (Shanghai) 46: 100-111, 2014.

10. Heo K, Kim YH, Sung HJ, et al: Hypoxia-induced up-regulation of apelin is associated with a poor prognosis in oral squamous cell carcinoma patients. Oral Oncol 48: 500-506, 2012.

11. Wang Z, Greeley GH Jr and Qiu S: Immunohistochemical localization of apelin in human normal breast and breast carcinoma. J Mol Histol 39: 121-124, 2008.

12. Poola I, DeWitty RL, Marshalleck JJ, Bhatnagar R, Abraham J and Leffall LD: Identification of MMP-1 as a putative breast cancer predictive marker by global gene expression analysis. Nat Med 11: 481-483, 2005.

13. Guan XY, Xu J, Anzick SL, Zhang H, Trent JM and Meltzer PS: Hybrid selection of transcribed sequences from microdissected DNA: Isolation of genes within amplified region at 20q11-q13.2 in breast cancer. Cancer Res 56: 3446-3450, 1996.

14. Anzick SL, Kononen J, Walker RL, Azorsa DO, Tanner MM, Guan XY, Sauter G, Kallioniemi OP, Trent JM and Meltzer PS: AIB1, a steroid receptor coactivator amplified in breast and ovarian cancer. Science 277: 965-968, 1997.

15. Bautista $S$, Vallès H, Walker RL, Anzick S, Zeillinger R, Meltzer P and Theillet C: In breast cancer, amplification of the steroid receptor coactivator gene AIB1 is correlated with estrogen and progesterone receptor positivity. Clin Cancer Res 4: 2925-2929, 1998

16. Bouras T, Southey MC and Venter DJ: Overexpression of the steroid receptor coactivator AIB1 in breast cancer correlates with the absence of estrogen and progesterone receptors and positivity for p53 and HER2/neu. Cancer Res 61: 903-907, 2001.

17. List HJ, Reiter R, Singh B, Wellstein A and Riegel AT: Expression of the nuclear coactivator AIB1 in normal and malignant breast tissue. Breast Cancer Res Treat 68: 21-28, 2001

18. Zhou HJ, Yan J, Luo W, Ayala G, Lin SH, Erdem H, Ittmann M, Tsai SY and Tsai MJ: SRC-3 is required for prostate cancer cell proliferation and survival. Cancer Res 65: 7976-7983, 2005.

19. Xu FP, Xie D, Wen JM, Wu HX, Liu YD, Bi J, Lv ZL, Zeng YX and Guan XY: SRC-3/AIB1 protein and gene amplification levels in human esophageal squamous cell carcinomas. Cancer Lett 245: 69-74, 2007.

20. Luo JH, Xie D, Liu MZ, Chen W, Liu YD, Wu GQ, Kung HF, Zeng YX and Guan XY: Protein expression and amplification of AIB1 in human urothelial carcinoma of the bladder and overexpression of AIB1 is a new independent prognostic marker of patient survival. Int J Cancer 122: 2554-2561, 2008.

21. Louie MC, Zou JX, Rabinovich A and Chen HW: ACTR/AIB1 functions as an E2F1 coactivator to promote breast cancer cell proliferation and antiestrogen resistance. Mol Cell Biol 24: 5157-5171, 2004.

22. Torres-Arzayus MI, Font de Mora J, Yuan J, Vazquez F, Bronson R, Rue M, Sellers WR and Brown M: High tumor incidence and activation of the PI3K/AKT pathway in transgenic mice define AIB1 as an oncogene. Cancer Cell 6: 263-274, 2004.

23. Tilli MT, Reiter R, Oh AS, Henke RT, McDonnell K, Gallicano GI, Furth PA and Riegel AT: Overexpression of an N-terminally truncated isoform of the nuclear receptor coactivator amplified in breast cancer 1 leads to altered proliferation of mammary epithelial cells in transgenic mice. Mol Endocrinol 19: 644-656, 2005.

24. O'Hara J, Vareslija D, McBryan J, et al: AIB1:ER $\alpha$ transcriptional activity is selectively enhanced in aromatase inhibitor-resistant breast cancer cells. Clin Cancer Res 18: 3305-3315, 2012.

25. Font de Mora J and Brown M: AIB1 is a conduit for kinase-mediated growth factor signaling to the estrogen receptor. Mol Cell Biol 20: 5041-5047, 2000.

26. Fereshteh MP, Tilli MT,Kim SE, Xu J, O'Malley BW, Wellstein A, Furth PA and Riegel AT: The nuclear receptor coactivator amplified in breast cancer-1 is required for Neu (ErbB2/HER2) activation, signaling, and mammary tumorigenesis in mice. Cancer Res 68: 3697-3706, 2008. 